\section{A imprensa e a emergência do jornalismo no Moçambique monárquico}

Isadora de Ataíde Fonseca ${ }^{1}$ José Luís Garcia ${ }^{2}$

Resumo: Observar a emergência da imprensa e do jornalismo em Moçambique na ótica da sociologia política no período da Monarquia Constitucional é o objetivo deste artigo. Os papéis desempenhados pelo jornalismo e as características do sistema de comunicação são identificados através da releitura da trajetória da imprensa com base nas teorias dos mídia. O período monárquico apresenta traços autoritários e liberais, e neste contexto a imprensa e o jornalismo desempenharam múltiplos papéis e influenciaram-no. A autonomia da imprensa no período é frágil face às forças políticas, a profissionalização é débil e a intervenção do Estado forte.

Palavras-chave: Moçambique; Regimes Políticos; Imprensa; Jornalismo; Relações Media-Império.

\section{The rise of the press and journalism in monarchic Mozambique}

Summary: In the perspective of political sociology, the main goal of this article is to observe the rise of the press and journalism in Mozambique in the course of Constitutional Monarchy. The roles developed by journalism and the features of media system are looked across the history of the press and analyzed by media theories. The monarchy time had authoritarian and liberal traces and in this context journalism and press performed different roles. In this period, autonomy of the press was weak in relation of political groups, professionalization was fragile and the State intervention was strong.

Keywords: Mozambique; Political Regimes; Press; Journalism; Media-Empire relationship.

1 Isadora de Ataíde Fonseca é jornalista, Mestre em Política Comparada e Doutoranda em Sociologia no Instituto de Ciências Sociais da Universidade de Lisboa (atalho@portugalmail.pt).

2 José Luís Garcia é Doutor em Ciências Socias pela Universidade de Lisboa e Investigador no Instituto de Ciências Sociais da Universidade de Lisboa desde 1998 (jlgarcia@ics.ul.pt).
É a liberdade de imprensa, seu instrumento e órgão, a mais preciosa e importante das liberdades.

(O Progresso, 09 de Abril de 1868, $1^{\circ}$ jornal independente em Moçambique)

\section{A emergência do jornalismo}

A Revolução Liberal

A primeira edição do Boletim Oficial, em 1854, é o despontar da imprensa em Moçambique. Os estudiosos do jornalismo adotaram diferentes perspectivas para o seu estudo. José Capela (1996) definiu dois períodos para estudar a imprensa na fase anterior à independência de Moçambique: 'Da fundação à censura prévia' e 'De 1926 a 1954'. Ilídio Rocha (2000) dividiu a história da comunicação impressa em oito períodos entre 1854 e $1974^{3}$. Hilário Matusse estabeleceu quatro etapas: a protonacionalista; a nacionalista; a nacional e a contemporânea ${ }^{4}$. Maria Cremilda Massingue (2000) definiu quatro momentos da imprensa: regida pelas 'regras e perfis da Metrópole'; a 'imprensa de combate'; o pós-independência e o pós-1990 (princípio da transição democrática). $\mathrm{Na}$ ótica da sociologia política, neste estudo a trajetória jornalística coincide com o regime político da Monarquia Constitucional (1854-1910).

\section{5}

Uma observação dos mídia e do jornalismo na Monarquia Constitucional e das características que moldaram a esfera da comunicação requer uma análise do contexto que levou Portugal a implementar a imprensa em Moçambique. As invasões francesas, a partida de D. João VI para a América, a revolução liberal, a independência do Brasil, o desenvolvimento da imprensa e o alargamento de espaços de politização, a crise econômica e os conflitos internos que permearam Portugal na primeira metade do século XIX são eventos cruciais para que se estabelecesse uma política para a África. É neste cenário que D. Maria II, em 1836, definiu uma lei orgânica para as colônias portuguesas africanas que incluiu gazetas oficiais. Depois da navegação, foi a imprensa que permitiu a Portugal romper com os limites da geografia na sua expansão para África.

É na década de 1820 que o jornalismo português procura um "rumo" e torna-se um meio de modelação

3 1854-1887; 1888-1898; 1898-1910; 1910-1918; 1919-1926; 1927 1951; 1952-1962; 1963-1974. ROCHA, I; A Imprensa de Moçambique. Lisboa, Edição Livros do Brasil. 2000, pg. II-VI.

4 A fase protonacionalista corresponde ao surgimento dos jornais independentes. $\mathrm{Na}$ etapa nacionalista são difundidas as problemáticas entre colonizador/colonizado. $O$ período nacional dá-se com a independêncida de Moçambique, em 1975. A fase contemporânea tem princípio na transição democrática em 199. MATUSSE, H.; Informação e Desenvolvimento: uma opinião. 1994, pg. 198. 
das dinâmicas políticas, econômicas, sociais e culturais (Tengarrinha, 1965). As dificuldades financeiras do Estado agravavam a insatisfação popular - abalada pela opção brasileira do rei quando das invasões francesas - e uma certa animação da sociedade civil brotava, fortalecia o sentido nacionalista e estimulava a revolta. O cenário foi propício para que em Agosto de 1820 os militares exigissem uma nova constituição. A revolução obrigou D. João a jurar a Constituição liberal quando regressou do Brasil. O documento era radical nos padrões da época: recusava o direito de veto ao rei extinguia a Inquisição e definia a liberdade de imprensa e de religião.

A partir de 1822 e até a Regeneração (1851) Portugal será abalado por uma série de conflitos políticos e militares que refletiam a disputa entre radicais e liberais. A revolução favorecia a emergência dos mídia e do jornalismo e estes levaram as informações e argumentos às camadas mais alargadas da população. Nascia uma imprensa de opinião que teria como tendência o alinhamento com os grupos e as forças sociais que disputavam o poder político e econômico em Portugal.

Em dezembro de 1834 é instaurada a lei da liberdade de imprensa. A comunicação política tem uma origem histórica anterior ao surgimento da imprensa, mas é com o jornal que tem início a estruturação de uma mediação técnica e profissional entre o poder e a sociedade. Em Portugal, a afinidade entre organizações noticiosas e forças políticas particulares surge como uma característica fundadora da imprensa.

\section{Horizonte africano}

O Portugal que nascia da revolução queria-se centrado na Europa e reduzia os poderes administrativos na colônia brasileira. Porém, manter os privilégios no outro lado Atlântico era necessário para a viabilização financeira do reino. Daí que a orientação política das Cortes Constitucionais e as diretivas econômicas do governo tenham sido as razões centrais para a independência do Brasil em 1822. E, não fosse a revolução promovida pelas elites brasileiras, quem teria se lembrado de África?

Enviar escravos para as plantações brasileiras era a função dos territórios africanos e em fins de século XVIII também a costa de Moçambique foi integrada na rota negreira. Se o comércio entre Portugal e África era insignificante, a independência do Brasil não deixou de afetar as colônias, nas quais lideranças locais cogitaram unir-se ao novo Estado americano. Foi o tratado luso -brasileiro de 1825 que garantiu as possessões africanas a Portugal.
Nas Cortes debatia-se o futuro das colônias africanas, estas surgiam como compensação para a perda do Brasil e como espaço da afirmação de Portugal no cenário internacional. É no fim da década de 1830 que emergem os mitos do Eldorado, "a crença na riqueza inabalável das colónias africanas”, e da Herança Sagrada, que "via na conservação de toda e qualquer parcela do território ultramarino um imperativo histórico" ". A ideologia colonial era propagada pelo conjunto das elites e procurava responder ao problema da identidade de um país que perdera o império, sofria uma crise e fora destroçado pela guerra civil. Assim, em 1836 foi criado o governo geral de Moçambique, no qual o governador tinha poder civil e militar.

Na época, a população autóctone de Moçambique utilizava as formas de comunicação simbólica dos bantus: a palavra falada, a linguagem gestual, as canções, as histórias, as gravuras, os sinais na vegetação, os tambores e os estafetas. Devido à presença árabe, já havia livros no território quando os portugueses aportaram, em 1498. A comunicação entre a população indígena e os portugueses deu-se através de intérpretes, de recados e da correspondência escrita. Logo que os primeiros colonos fixaram-se no território trouxeram consigo as cartinhas e os catecismos, os livros impressos que iriam predominar até a introdução da tipografia (Gonçalves, 1965).

\section{O despontar jornalístico}

Após a aliança entre liberais e conservadores estabelecida pela Regeneração em 1851, reforçar a presença e a soberania portuguesa em Moçambique eram as prioridades. O papel do Estado era limitado ao impulso financeiro inicial, à eliminação dos entraves para a produção e ao estímulo dos circuitos mercantis. Logo, a legislação colonial centrava-se na abertura dos portos e na melhoria das rotas de transporte interno.

É neste contexto que foi publicada a primeira edição do Boletim Oficial em Moçambique. "A imprensa é um dos melhores inventos do espírito humano", assinalava o texto do então governador, Vasco Guedes de Carvalho e Meneses, em 13 de maio de 1854. Liberal e partilhando da mundividência do progresso, o decreto que instituíra os boletins oficiais nas colônias africanas (1836) previa que se publicassem as ordens do reino, as notícias marítimas, preços, informações estatísticas e "tudo o que for interessante para conhecimento do público". A imprensa e a tipografia nacional estariam instalados na Ilha de Moçambique, então capital da colônia, até 1898. Em-

5 ALEXANDRE, V. A questão colonial no Portugal oitocentista. 1998, pg. 42-43. 
bora tenha sofrido alterações, o Boletim Oficial manteve-se até 1975 e foi o mais estável, e daí sua importância, meio de informação escrita de Moçambique durante o século XIX. Porém, o público leitor era reduzido, o que se explicava pela diminuta população alfabetizada, pela fraca circulação de papel e pelo custo do jornal. Meios de transporte, escrita e imprensa, de forma não monolítica e sujeita nuances, constituíam um complexo midiático de articulação com o império português e o seu legado.

A partir da década de 1860 os conflitos ideológicos e sociais voltaram a ganhar força em Portugal. Os adeptos da visão do progresso pretendiam imprimir ao regime uma dinâmica democrática que conduzisse a uma república. A oposição ao governo na metrópole passava pela questão colonial, que confrontava o atraso das colônias às riquezas que estas deveriam trazer ao império.

As lutas políticas que se desenrolavam na metrópole desdobravam-se em termos locais no jornalismo que despontava. Embora efêmera, a vida do primeiro jornal independente teve o cunho político e de opinião que marcará o percurso da imprensa em Moçambique. A edição única de O Progresso, em 09 de Abril de 1868, anunciava que o jornal pretendia-se 'hebdomadário religioso, instrutivo, comercial e agrícola'. O artigo editorial valorizou a liberdade de imprensa e o conteúdo informativo noticiou um caso judicial que envolvia os interesses do governador. Daí que dois dias depois fosse instituída a censura. $\mathrm{O}$ despacho do governador ordenava que o jornal não deveria incluir "correspondência de natureza política ou pessoal" e que uma prova deveria ser remetida à secretaria-geral antes da sua impressão para receber o "visto".

Desenvolver a economia sem liberalizar politicamente o regime permaneceram como as diretrizes do governo português na década de 1870 . O projeto colonial era retomado, favorecido pelo arranque do comércio na zona litoral. A liberalização mercantil chegou em 1877 a Moçambique e coincide com a polêmica concessão de terras na Zambézia para o plantio de ópio. Assim, a entrega de território a Paiva de Andrade provocou o surgimento do primeiro jornal de oposição ao governo. A partir de Quelimane também se publicava $O$ Africano, 'Instrução - Religião - Moralidade'. Semanário, editado até 1881, "não estava nem com o poder estabelecido nem com os militares que o controlavam", denunciava a corrupção na métropole e a paralisia do governo por não fomentar o desenvolvimento da colônia. A nova dinâmica implicava que a imprensa da colônia e os seus

6 ROCHA, I; A Imprensa de Moçambique. Lisboa, Edição Livros do Brasil. 2000, pg, 47. interesses nem sempre fossem convergentes com os da metrópole.

Outros periódicos surgiram na Ilha de Moçambique. Em resposta as limitações legais, os editores adotaram a estratégia de substituir os títulos dos jornais para manterem-se na rua quando as publicações eram suspensas ou censuradas. O semanário A Imprensa - 'político, literário e noticioso' - foi publicado entre 1870-73. A partir de 1872 vem a público o bissemanal Noticiário de Moçambique. Propriedade de tipógrafos, passará a Jornal de Moçambique em 1873. Três anos depois, em 1876, o periódico tornar-se-ia África Oriental, o primeiro jornal a contar com tipografia própria, publicado até 1887. Dias (1954:51) regista que o África Oriental tinha “características governamentais, pois dizia bem de todos os governadores da Provincía a propósito de tudo e de nada".

\section{Interesses privados}

A recessão capitalista da década de 1880 e a procura pelos mercados africanos levou a Europa à partilha de África na Conferência de Berlim, em 1884. Os jornais que emergiram nesta década davam continuidade a uma imprensa crítica ao governo colonial, embora fiel à ocupação. Daí que O Gato, 1880-82, na Ilha de Moçambique fosse criticado pela imprensa leal ao governo como "ridículo órgão jornalístico, ínfimo excremento de literatura nacional". Ainda que a vida dos jornais fosse curta, os títulos que surgiram eram críticos ao governo. Entre eles, na Zambézia, contam-se O Quelimanense (1881-83); O Vigilante (1882-83); Correio da Zambézia (1886-87) e Gaz̧eta do Sul (1889-1891).

A condição de vila de Lourenço Marques a partir de 1888 e os interesses econômicos e políticos da Sociedade de Geografia de Lisboa levaram a criação do primeiro semanário na região Sul. O Distrito de Lourenço Marques, 1887-88, fundado por sócios da Sociedade, defendia a política colonial e teve como eixo temático a transferência da concessão do caminho-de-ferro dos britânicos para os portugueses. O jornalismo era portavoz dos interesses das forças sociais e terá sido mesmo criado com este fim, pois quando terminou a polêmica este deixou de ser publicado (Rocha, 2000).

A crise do Ultimatum inaugurou a década de 1890 e impôs novos cenários em Moçambique. A retirada portuguesa de territórios a Noroeste de Moçambique, exigida pelos britânicos, fez explodir o nacionalismo português, sacralizou a noção de império, reavivou o racismo com argumentos científicos e reforçou o protecionismo econômico (Clarence-Smith, 1985). 
É neste clima que aparecem novos jornais em Lourenço Marques. Publicado durante dois meses, em 1890 surgiu o semanário A Situação, de opinião e defensor da política colonial. O Comércio de Lourenço Marques saiu às ruas entre 1892-93 e estava ligado aos interesses dos comerciantes da cidade. O primeiro jornal noticioso foi o semanário bilíngue O Futuro de Lourenço Marques, 1894-95, os interesses comerciais ingleses justificavam o enfoque econômico e os anúncios. Porém, as notícias sobre as revoltas da população indígena e sobre as operações militares de repressão levaram a sua suspensão. Três anos depois, com o título $O$ Futuro, o semanário reapareceria e seria publicado até 1908. A distribuição gratuita e os textos em inglês diferenciavam o The Lourenzo Marques Advertiser, publicado semanalmente entre 1898-99.

Ceder territórios em Manica, na Beira, no Niassa e na Zambézia para investidores privados foi a solução encontrada pela coroa para transferir a administração do país na zona acima do rio Save. A partir da década de 1890 as Companhias de Moçambique, da Zambézia e do Niassa usaram da força para submeter a população e controlar os territórios, cobrar impostos e recrutar mãode-obra (Newitt, 1995).

Como todo o projeto econômico tende a ser acompanhado por um discurso ideológico, a Companhia de Moçambique instalou uma tipografia na qual imprimiu o Boletim da Companbia de Moçambique entre 18921942. Em 1893 surgia o Correio da Beira, quinzenário, noticioso, bilíngue e com correspondentes locais e na África Austral. Porém, faltava-lhe independência, não só imprimia-se na tipografia da Companhia como defendia a sua política. Com interrupções, mudanças de título e de linha editorial, o Correio da Beira chegaria a 1981. Com o mesmo fim de defender a administração privada do território, entre 1897 e 1929 foi publicado o Boletim da Companbia do Niassa. Críticos ao governo surgiram na década 1890 na Zambézia os periódicos privados Clamor Africano (1892-94) e Eco da Zambéria (1893-95).

A mudança da capital para Lourenço Marques e a concessão dos territórios a Norte foram decisivas para nutrir a imprensa e os espaços de politização e debate público que emergiam e que se fortaleceram a partir do século XX. Ainda que de curta duração, os jornais desta época passaram a reproduzir também os interesses econômicos dos grupos, para além das opiniões políticas, o que contribuiu para alinhamentos entre a imprensa e as forças políticas.

\section{Jornalismo e ideologia}

O Ultimatum reavivou o nacionalismo português, aumentou a descrença no rei e fortaleceu o movimento republicano. Ainda que em Moçambique os partidos políticos não tivessem uma vida orgânica, que os conflitos sociais não tivessem emergido, que a revolta indígena fosse esmagada e que a colônia estivesse a ingressar nos debates da modernidade, as diferenças entre monárquicos e republicanos reproduziam-se no quotidiano e traduziam-se na imprensa.

A pretensão de que as colônias fossem tratadas como membros da métropole viu-se frustrada pela reorientação política da década de 1890. A partir de 1899 a lei reconhecia duas classes de cidadãos. Os não-indígenas tinham os mesmos direitos reconhecidos aos portugueses da metrópole, enquanto os indígenas eram submetidos à tradição africana e às leis coloniais que regulamentavam os impostos e o trabalho.

Lourenço Marques integrava o circuito comercial da África do Sul, crescia e afirmava-se como capital política e pólo econômico. Neste ambiente é publicado entre 1903-04 o The Delagoa Gazette of Shipping and Commercial Intelligence, o primeiro jornal diário de Moçambique. Voltaria em 1908 como Delagoa Bay Gazette e seria mensal até 1911. O bissemanário The Lourenço Marques Guardian, bilíngue, surgiu em 1905 e manter-se-ia até 1951.

É no princípio do século que os maçons afirmam-se e constituem um setor burguês colonial republicano. 'Semanário independente, noticioso, literário e comercial' é como se anuncia $O$ Português, jornal republicano fundado pelos maçons e que seria suprimido dois meses após a sua fundação por "denúncia das irregularidades cometidas pelos dirigentes municipais" (Rocha, 2000:81). O mesmo grupo irá publicar a partir de 1902 O Progresso de Lourenço Marques, também censurado. Seguese o Progresso de Lourenço Marques, que em 1906 foi assaltado por monárquicos e teve a sua tipografia destruída.

Em reação à propaganda republicana aparece entre 1901-02 o Imparcial, que embora crítico à administração defendia o regime monárquico. Semanário, era propriedade de advogados e comerciantes. Também crítico ao governo e defensor da monarquia foi o Jornal do Comércio, propriedade de advogados, negociantes e latifundiários, publicado entre 1904-05.

O Distrito era republicano e tinha como proprietários jornalistas, pretendia-se noticioso e queria sobreviver dos anúncios e das vendas. Foi diário entre 1904-1905, quando suspenso por ter publicado artigos ofensivos às autoridades locais. Voltou às ruas 15 dias 
depois como Diário de Notícias, mantendo-se até 1907. O humor também serviu à oposição monárquica em $O$ Mignon, 'Semanário humorístico, ilustrado', publicado em 1902.

Moçambique abrigou a partir de 1896 operários expulsos da métropole pela Monarquia. Foram estes que fundaram em 1899 a Associação de Classe dos Empregados do Comércio e Indústria de Lourenço Marques, que publicava panfletos e edições únicas em datas como o $1^{\circ}$ de Maio. Daí que tenha sido um metalúrgico o fundador e proprietário do Vida Nova, 'Semanário Republicano', crítico do regime e das elites econômicas locais. Com jornalistas ameaçados e espancados, o jornal sobreviveu à condenação por delito de imprensa em 1908, mas não à destruição da sua tipografia em 1910. Também se assinalam as edições únicas dos jornais libertários Pró-Mártir e $O$ Chocarreiro, que defendiam a unidade dos trabalhadores.

A aceitação de indígenas na Escola $1^{\circ}$ de Janeiro, o trabalho social da Missão Suíça, a chefia dos serviços públicos por maçons e a carência de recursos humanos foram fatores que colaboraram para que surgisse uma elite negra em Lourenço Marques. Os irmãos João e José Albasini foram líderes desta elite, que reivindicava direitos e liberdades para os africanos através do semanário $O$ Africano a partir de 1909.

Um jornalismo crítico dos governos monárquicos e radical na medida em que defendia a revolução republicana emergiu em Moçambique nesta primeira década do século XX. A publicação de títulos orientados para as notícias e para os temas econômicos caracterizam uma nova etapa da imprensa na colônia. Apesar das limitações impostas pelo governo e pelas forças sociais, os jornais deste período inauguram os conflitos entre classes, africanos e europeus. A censura governamental indica que os espaços de discussão pública e a imprensa desenvolviam-se em Moçambique. O panorama evidencia relações nem sempre ajustadas entre, por um lado, os produtores e difusores de notícias mais ligados aos interesses políticos do império português e, por outro lado, certos jornais editados em Moçambique, na medida em que os seus proprietários e leitores procuravam outro tipo de informação. A imprensa em Moçambique manifestava uma certa capacidade de autonomia, apesar de muito tutelada.

\section{Liberalismo para Europeus e Protagonismo Jornalístico}

O fim do regime absoluto implementou em Portugal liberdades civis e políticas, mas os processos elei- torais não eram livres, a participação era limitada e as instituições não eram autônomas. Com a Regeneração os processos eleitorais tornaram-se regulares em Portugal. Estes estimulavam a dinamização da vida política, mas tinham como funções legitimar e confirmar o poder, promover a integração e recrutar e selecionar as elites (Almeida, 1991:28-31). O debate sobre a representação legislativa das colônias ao longo da Monarquia Constitucional foi intenso (Silva, 2010). Contudo, em Moçambique a estrutura organizativa dos partidos políticos não se fazia sentir (Lopes, 2010). Cabia à colônia do Índico ser representada por dois deputados, eleitos em 1890 pelos $595^{7}$ eleitores registados, excluídos os africanos.

A progressiva participação política do povo em Portugal ao longo do século XIX não incluiu as colônias portuguesas. O século XIX não trouxe para Moçambique uma condição de cidadania que incluísse os africanos. Pelo contrário, os diferenciava através da lei, da força, dos arranjos políticos, econômicos e sociais. Em Moçambique tardaram as conquistas liberais, e quando desembarcaram não se destinavam aos africanos.

A primeira lei para as colônias africanas foi a que criou o Boletim Oficial, em 1836. Vinte anos mais tarde, em 1855, uma portaria definiu os conteúdos que poderiam ser veiculados pelo $\mathrm{BO}$ e a sua regularidade semanal. A legislação de 1856 estabeleceu que os juízes do ultramar eram competentes para julgarem os crimes contra à liberdade de imprensa. A lei também limitava os editores responsáveis aos cidadãos elegíveis para as cortes. Por fim, a lei de imprensa de 1866 estendia-se às colónias africanas.

"Desconhece-se quase em absoluto a forma como era aplicada esta legislação", observa Sopa sobre a censura em Moçambique (1991:254). Como se viu, $A$ Imprensa de Moçambique (Rocha, 2000) ilustra inúmeros casos de repressão ao jornalismo ao longo da Monarquia Constitucional. A censura prévia, a supressão e apreensão de jornais, a proibição de periódicos, a destruição de tipografias, a perseguição e a prisão de jornalistas são incidentes que fizeram parte da emergência da imprensa em Moçambique. A repressão à imprensa foi uma reação às críticas ao regime e ao governo local, à resistência às políticas económicas e administrativas e aos defensores dos ideais republicanos. Quando despontaram os primeiros conflitos entre classes em Moçambique a partir da imprensa operária e de humor, também estes foram reprimidos. As identidades locais e de classe aglutinaramse e disseminaram-se em torno das comunicações, das notícias e das reportagens dos acontecimentos.

7 NEWITT, M.; História de Moçambique. Mem Martins, Publicações Europa América. 1997, pg. 337. 


\section{A perspectiva autoritária}

A licença de impressão, a censura e a perseguição aos jornalistas são os principais métodos para que a imprensa cumpra com o seu papel de sustentar as políticas de governo. A implantação do Boletim Oficial em Moçambique coincide com a retomada dos interesses do império português em África. O decreto que estabeleceu o BO prescrevia-o como um canal de divulgação das decisões do regime e do governo e salientava as informações noticiosas de caráter econômico. Logo, a imprensa oficial deveria contribuir para que as ordens da coroa fossem disseminadas e cumpridas e para estimular o desenvolvimento do território. As companhias que se instalaram em Moçambique com a missão de pacificar, administrar e desenvolver o território atuavam como Estados e também criaram os seus boletins como instrumentos de suporte ideológico.

A censura foi a primeira e a principal tática para coibir às críticas. Como se viu, a liberdade e a repressão à imprensa alternaram-se na medida dos conflitos políticos e das leis. Mesmo nos períodos em que as disputas entre as elites traduziram-se em legislações liberais, a perseguição contra os jornalistas fez-se sentir na metrópole e reproduziu-se em Moçambique. De fato a censura foi mais dura no Índico, visto que os governadores acumulavam poderes e exerciam pressão direta sobre os juízes de modo a restringir o jornalismo. A vida curta da maioria dos jornais neste período e a frequente mudança de título foram sobretudo determinadas pela censura. Em Moçambique os diferentes modos de controlo da imprensa e do jornalismo característicos dos modelos autoritários foram aplicadas de modo a suportar os governos e suas arbitrariedades. Dado que os interesses de parcela significativa das elites econômicas coincidiam com os dos governos, estas também eram defendidas através da repressão à imprensa.

\section{A perspectiva democrática}

Para superar uma visão "tradicional" de análise da imprensa - na qual o jornalismo desempenha os papéis de estabilizar e manter a ordem política nos regimes autoritários e são garantes das liberdades políticas nas democracias - esta releitura implica a observação da imprensa a partir das teorias do jornalismo em democracia. Daí que os papéis Monitor, Colaborador, Radical e Facilitador - desenvolvidos no âmbito das teorias normativas dos media por Christians et al (2009) - sejam atraentes para pensar o jornalismo em Moçambique.

8 GUNTHER, R.; MUGHAN, A. The Media in Democractic and Nondemocratic Regimes: A Multilevel Perspective. 2000, pg.03-04.
"The natural first role is that of vigilant informer, which applies mainly to collecting and publishing information of interest to audiences", definem Christians et al (2009:30) sobre o papel Monitor. Diversas das práti-

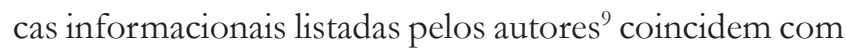
os relatos dos historiadores da imprensa moçambicana. Em diferentes medidas, todos os jornais publicaram os eventos da sua época e disseminaram notícias locais e internacionais. Ainda que o país estivesse num estágio proto-capitalista ${ }^{10}$, surgiram em Lourenço Marques diversos jornais com enfoque econômico. Embora o regime limitasse a participação política dos europeus e inexistissem fóruns de representação para os africanos, as políticas do império e as práticas da administração foram o tema privilegiado na imprensa da época. Se individualmente os jornais não incluíam a diversidade de opiniões das forças sociais, no seu conjunto a imprensa reportou as diferenças ideológicas entre os grupos. O Boletim Oficial e os boletins das companhias cumpriram o papel de mediar governo e cidadão. De extrema relevância foi a monitoria do setor público e privado. Ainda que moderado e pontual, o papel jornalístico de cão-de-guarda dos interesses públicos manifestou-se nas denúncias de corrupção das administrações locais.

O papel Colaborador refere-se à relação direta entre a imprensa e o governo, implica que o jornalismo corrobore as políticas e práticas do regime para que as metas destes sejam atingidas. A colaboração concretizase por coperação, coerção e/ ou instrumentalização. Nesta ótica o Boletim Oficial do governo e os boletins das companhias são casos típicos de colaboração por coperação, visto que nestes as práticas informacionais estiveram voltadas para o fortalecimento da autoridade. Como se viu, diversos jornais privados do período monárquico assumiram a defesa dos governos locais, quer por suas crenças ou para garantir os seus interesses econômicos através da instrumentalização do jornalismo.

A luta pela igualdade e a liberdade entre os indivíduos e o compromisso para que o poder seja distribuído entre os grupos caracterizam o papel jornalístico Radical. Representar os grupos minoritários e suportar

9 1. Publicar uma agenda de eventos; 2. Disseminar notícias a partir de fontes externas; 3. Cobrir os fóruns de decisão política e económica; 4. Publicar reportagens; 5. Informar o público sobre os riscos e as ameaças; 6. Providenciar um guia da atitudes do grupos sociais; 7. Apresentar uma agenda dos problemas sociais; 8. Providenciar análise e opinião dos eventos; 9. Mediar cidadão e governo; 10. Monitorar as forças e os actores que agem contra o interesse público; 11. Desenvolver investigação própria sobre temas relevantes. CHRISTIANS, C.G. et al. Normative Theories of The Media, Journalism in Democratic Societies. Chicago, University of Illinois Press. 2009, pg. 145-46).

10 PROENÇA, M. C.; A questão colonial, 2009, pg. 205-228. 
os movimentos para mudanças macro-estruturais são objetivos do jornalismo radical. Nesta perspectiva podese enquadrar a emergente imprensa operária e anárquica da primeira década do século XX. A interpretação de Capela (2010:151) é que a imprensa operária de Lourenço Marques foi "aguerridamente combativa". Os jornais que defendiam os ideais republicanos também podem ser observados neste viés, visto que a mudança de regime, e as suas implicações nas dinâmicas sociais, implicava uma revolução.

Facilitar os processos sociais, a construção de consensos e a tomada de decisão sem comprometer a integridade, a credibilidade e a independência jornalística é o papel da imprensa no modelo normativo Facilitador. Não há indicadores de que a emergente imprensa e esfera pública moçambicana durante a monarquia tenha desempenhado este papel de facilitar a vida política.

\section{Um sistema de imprensa}

O Estado e as companhias privadas foram proprietários de jornais em Moçambique. Um segundo grupo é o dos negociantes e o terceiro segmento é o dos jornalistas e tipógrafos. No século XX aparecem os jornais de propriedade das associações de trabalhadores e de africanos. A utilização do português e do inglês na imprensa implicou uma circulação restrita às elites européias. O censo de 1912 aponta que viviam em Lourenço Marques 5.560 brancos e 2.898 indianos, o que implica um número reduzido de leitores visto o analfabetismo da maioria da população negra. Como em Portugal, a baixa circulação da imprensa em Moçambique foi determinante para que esta não se tornasse um negócio.

Os conteúdos veiculados pela imprensa neste período indicam uma forte conformidade política no jornalismo. Nota-se também uma conexão entre os proprietários dos jornais com as idéias que representam, a exemplo dos maçons e dos anarquistas. Nesta linha, a coincidência entre os que eram jornalistas e estavam envolvidos na vida política - o que incluía pessoal da administração pública, representantes de interesses privados e de grupos sociais. A prevalência do jornalismo de opinião, que atuava como um divulgador das ideologias e dos conflitos da época, também corrobora a afinidade paralela entre o jornalismo e as forças políticas. Por fim, o pluralismo externo (a variedade de jornais no conjunto da imprensa a expressar as diferentes tendências políticas) aponta para o paralelismo político durante a Monarquia Constitucional.

Os jornalistas em Moçambique não se tinham afirmado enquanto profissionais e dependiam de outras atividades. Assim, os profissionais tiveram limitada autonomia, quer pelos fatores econômicos ou pelos compromissos políticos dos jornais. As normas profissionais e os códigos de ética, os sindicatos profissionais e a formação educacional não tinham emergido neste período em Portugal ou nas suas colônias, indicador de uma incipiente profissionalização. As características identificadas na dimensão do alinhamento político e da profissionalização apontam ainda para a tendência de instrumentalização da imprensa na medida em que esta era controlada por actores externos aos meios de comunicação para intervir e influenciar o ambiente político.

O Estado desempenhou em Moçambique um papel forte no sistema de imprensa. Foi proprietário, legislou para limitar a liberdade de imprensa, exerceu a censura, usou da força para suprimir o jornalismo quando este não coincidia com os seus interesses e restringiu o acesso às informações de interesse público. Apesar das legislações liberais, que tiveram menor efetividade na colônia do que na metrópole, a intervenção do Estado procurou controlar a atividade jornalística e de imprensa de modo a concretizar os seus interesses.

\section{Conclusões}

As reformas políticas, sociais e econômicas que resultaram da Revolução Liberal estenderam-se gradativamente às colônias africanas. Porém, o olhar para África teve o fortalecimento do império português e o desenvolvimento econômico como motivações. José Capela (2010) assinala o princípio do Estado colonial moderno em Moçambique na década de 1870, com a ocupação militar e a administração civil aliadas ao capital internacional que modernizou a economia e configurou os espaços urbanos. Entre as consequências da consolidação do Estado colonial a perda da independência dos territórios africanos; a "negação do homem africano" e a segregação; a expropriação das terras para a agricultura e o trabalho forçado; a integração na economia capitalista e a transformação das instituições sociais ${ }^{11}$.

Os estímulos iniciais ao desenvolvimento da imprensa integravam-se na estratégia colonial para Moçambique. Entretanto, surgiram vozes de resistência ao império, se bem que não ao projecto colonial em si e mais às suas opções e estratégias locais. Desde o princípio a imprensa esteve relacionada com os interesses políticos, económicos e ideológicos das elites européias que ocupavam o território. Somente no princípio do século XX irá surgir uma imprensa que põe no primeiro plano os con-

11 História de Moçambique - Agressão Imperialista; 1983, pg. 301 15. 
teúdos noticiosos e informativos. Do mesmo modo o impulso industrial e urbano propiciou o aparecimento de um jornalismo crítico das relações econômicas capitalistas. Na véspera da transição da Monarquia para a República, com $O$ Africano, surge uma imprensa que questiona as relações entre europeus e africanos.

A chegada da imprensa em Moçambique transporta muitas das características e das dinâmicas da trajetória política e do jornalismo em Portugal. Em 56 anos a imprensa afirmou-se como canal privilegiado de expressão das elites dirigentes e dos grupos. A imprensa foi uma aliada do sistema político, mas também contribuiu para influenciar e transformar o regime e a administração através da defesa dos ideais republicanos e da denúncia da corrupção.

Na sua origem e ao longo da Monarquia Constitucional a imprensa em Moçambique apresentou baixa circulação e propriedade dos grupos sociais; forte alinhamento político e instrumentalização; fraca profissionalização e grande intervenção do Estado ${ }^{12}$. E é com estes pilares que o jornalismo e a imprensa irão florescer em Moçambique durante a República e fortalecer o seu papel de ator político.

\section{Referências bibliográficas:}

ALEXANDRE, V. A questão colonial no Portugal oitocentista. In: Serrão, J.; Marques, A.H.O. (direcção). Nova História da Expansão Portuguesa, O Império Africano $1825-$ 1890, Volume X, Alexandre, V.; Dias, J. (coordenadores do volume). Lisboa, Editorial Estampa, 1998. p. 21-132.

ALMEIDA, P.T.; Eleições e Caciquismo no Portugal Oitocentista (1868-1890). Lisboa, DIFEL.1991. 322 p.

BONIFÁCIO, M. F; A Monarquia Constitucional, $1807-$ 1910. Alfragide, Texto Editores. 2010. 216 p.

12 "Political parallelism tend to be high; the press is marked by a strong focus on political life, external pluralism, and a tradition of commentary-oriented or advocacy journalism persists more strongly than in other parts of Europe. Instrumentalization of media by the governments, by political actors, and by industrialists with political ties is common. Professionalization of journalism is not a strongly developed as in other models: journalism is not a as strongly differentiated from political activism and the autonomy of journalists is often limited, though, as we shall see, the Mediterranean countries are characterized by particularly explicit conflicts over the autonomy of journalists - power and authority within news organizations has been more openly contested in the Polarized Pluralist systems. The state plays a large role as an owner, regulator, and funder of media, though its capacity to regulate effectively is often limited", HALLIN, D. C.; MANCINI, P. Comparing Media Systems, Three Models of Media and Politics. Cambridge, Cambridge University Press. 2004, pg. 73).
CAPELA, J.; A imprensa de Moçambique até à Independência, in 140 Anos de Imprensa em Moçambique, Fátima Ribeiro e António Sopa (coordenadores). Maputo, Associação Moçambicana da Língua Portuguesa. 1996. 303 p.

CAPELA, J.; A imprensa de Moçambique até à independência, 1854-1974, in Moçambique pela sua História, José Capela. V.N. Famalicão, Edições Húmus. 2010. 173 p.

CARVAlHO, S.; História de Moçambique, Volume 2, Agressão Imperialista (1886/1930). Maputo, Departamento de História da Universidade Eduardo Mondlane e Revista Tempo. 1983. 336 p.

CLARENCE-SMITH, G.; O Terceiro Império Português (1825-1975). Lisboa, Editorial Teorema. 1985. 272 p.

CHRISTIANS, C.G. et al. Normative Theories of The Media, Journalism in Democratic Societies. Chicago, University of Illinois Press. 2009. 296, p.

DIAS, R.N.; Quatro Centenários em Moģambique, 1854 1954. Lourenço Marques, Imprensa Nacional de Moçambique. 1954.84 p.

GONÇALVES, J. J.; A Informação em Moçambique (Contribuição Para o Seu Estudo). Lisboa, Companhia Nacional Editora. 1965.

GUNTHER, R.; MUGHAN, A. The Media in Democractic and Nondemocratic Regimes: A Multilevel Perspective, in Democracy and the Media, A Comparative Perspective, Richard Gunther e Anthony Mughan (editores). Cambridge, Cambridge University Press. 2000. 496, p.

HALLIN, D. C.; MANCINI, P. Comparing Media Systems, Three Models of Media and Politics. Cambridge, Cambridge University Press. 2004. 342, p.

LOPES, F. F.; Partidos e representação política no período liberal em Portugal. In: Catroga, F.; Almeida, P.T. (coordenadores). RES publica: cidadania e representação política em Portugal, 1820-1926. Lisboa, Assembleia da República, Biblioteca Nacional de Portugal. 2010. 335 p.

MASSINGUE, M. C.; A Imprensa, o Estado e a Democracia. Maputo, Promédia. 2000. 69 p.

MATUSSE, H.; Informação e Desenvolvimento: uma opinião. In: Mendes, J. A Nossa Situação, o Nosso Futuro e o Multipartidarismo. Maputo, Tempográfica. 1994. 220 p. 
NEWITT, M.; História de Moçambique. Mem Martins, Publicações Europa América. 1997. 512 p.

PROENÇA, M. C.; A questão colonial (205-228). In: Rollo, M.F.; Rosas, F. (coordenadores). História da Primeira República Portuguesa. Tinta da China. 2009. 616 p.

ROCHA, I; A Imprensa de Moçambique. Lisboa, Edição Livros do Brasil. 2000. 440 p.

SILVA, C. N.; Cidadania e representação política no Império. In: Catroga, F.; Almeida, P.T. (coordenadores). RES publica: cidadania e representação política em Portugal, 1820-1926. Lisboa, Assembleia da República, Biblioteca Nacional de Portugal. 2010. 335 p.

SOPA, A.; Liberdade de Imprensa e Regime de Censura Prévia: O Caso Moçambicano 1985-1975. In: José, A.; Meneses, P. M. G. (editores). Moçambique 16 anos de Historiografia: Focos, Problemas, Metodologias, Desafios para a Década de 90. Maputo, CEGRAF. 1991. 315 p.

TENGARRINHA, J.; História da Imprensa Periódica Portuguesa. Lisboa, Portugália Editora. 1965. 349 p.

Recebido: $10 / 02 / 2013$

Aprovado: 22/04/2013 